\title{
Effect of mannanoligosaccharides and/or enzymes on antibody titers against infectious bursal and Newcastle disease viruses
}

\author{
[Efeito do mananoligossacarídeo elou enzimas sobre títulos de anticorpos contra os vírus \\ das doenças de Gumboro e de Newcastle] \\ M.C. Oliveira ${ }^{1}$, D.F. Figueiredo-Lima ${ }^{2}$, D.E. Faria Filho ${ }^{3}$, R.H. Marques ${ }^{4}$, V.M.B. Moraes ${ }^{4}$ \\ ${ }^{1}$ Faculdade Medicina Veterinária - FESURV \\ Caixa Postal 244 \\ 75901-970 - Rio Verde, GO \\ ${ }^{2}$ Centro de Ciências Agrárias - UFPB - Areia, PB \\ ${ }^{3}$ Núcleo de Ciências Agrárias - UFMG - Montes Claros, MG \\ ${ }^{4}$ Faculdade de Ciências Agrárias e Veterinárias - UNESP - Jaboticabal, SP
}

\begin{abstract}
The effect of including mannanoligosaccharides (MOS) and/or enzymes in broiler diets on antibody titers against infectious bursal disease virus (IBDV) and Newcastle disease virus (NDV) was evaluated. A total of 750 broilers were distributed into a completely randomized experimental design in a factorial arrangement $2 \times 2+1$ with two levels of MOS ( 0 and $0.1 \%$ until 21 days and $0.05 \%$ from 22 to 42 days of age), two levels of enzymes ( 0 and $0.05 \%)$ and a positive control diet containing antibiotic, totaling five treatments with five replicates each. For antibody analyses, blood samples were weekly collected by jugular vein puncture in the same two birds per replicate. The first and last collections were done at 7 and 42 days of age, respectively. The inclusion of MOS resulted in increased antibody titers against IBDV in the fourth $(\mathrm{P}<0.03)$ and fifth $(\mathrm{P}<0.02)$ weeks, and against NDV in the third $(\mathrm{P}<0.01)$, fourth $(\mathrm{P}<0.03)$ and fifth $(\mathrm{P}<0.03)$ weeks of age. MOS was effective in stimulating the humoral immune responses against IBDV and NDV vaccine viruses.
\end{abstract}

Keywords: broiler, additive, humoral immune modulation, prebiotic

\section{RESUMO}

O efeito da inclusão de mananoligossacarídeo (MOS) elou enzimas em dietas de frangos sobre os títulos de anticorpos contra os vírus das doenças de Gumboro (VDG) e de Newcastle (VDN). Setecentos e cinqüenta aves foram distribuídas em um delineamento experimental inteiramente ao acaso, em arranjo fatorial $2 \times 2+1$, com dois niveis de MOS ( 0 e 0,1\% até 21 dias e 0,05\% de 22 até 42 dias de idade), dois niveis de enzimas (0 e 0,05\%) e uma dieta-controle-positivo contendo antibióticos, totalizando cinco tratamentos com cinco repetições. Para análise dos anticorpos, amostras de sangue foram colhidas semanalmente por punção da veia jugular em duas aves de cada repetição. A primeira e a última colheita foram realizadas aos sete e 42 dias de idade, respectivamente. A inclusão de MOS resultou em aumento dos titulos contra VDG na quarta $(P<0,03)$ e quinta $(P<0,02)$ semanas, e contra VDN na terceira $(P<0,01)$, quarta $(P<0,03)$ e quinta $(P<0,03)$ semanas de idade. $O$ MOS foi efetivo em estimular a resposta imune humoral contra VDG e VDN vacinais.

Palavras-chave: frango, aditivo, imunomodulação humoral, prebiótico

Recebido em 26 de maio de 2008

Aceito em 5 de dezembro de 2008

E-mail: cristina@fesurv.br 


\section{INTRODUCTION}

Mannanoligosaccharides are derived from the yeast cell wall (Saccharomyces cerevisiae) and they not only promote the microflora balance but also have immunomodulation properties. Inflammatory immune responses are associated with nutrient mobilization during growing phase and lower feed intake. Thus, dietary immunomodulators that increase humoral immunity and decrease the immunological stress will affect broiler performance (Ferket, 2004).

The immunomodulating mechanism of MOS remains unknown. Defense cells in the liver detect some molecules known as pathogens associated molecular pattern that are specific of each microorganism. These molecules include yeast cell wall, peptoglycans, lipopolysaccharides, and glycolipids (Shashidhara and Devegowda, 2003). MOS also reduces pathogen colonization by acting as an analogous receptor to type I fimbriae and by decreasing the number of binding sites in the intestine (Patterson and Burkholder, 2003).

Maize has approximately $0.9 \%$ of soluble and $6 \%$ of insoluble non-starch polysaccharides (NSP), while soybean meal has approximately $6 \%$ of soluble and $18-20 \%$ of insoluble NSP (Kocher et al., 2003). Another dietary carbohydrate - starch - is partially digested in the small intestine. The remaining fraction (resistant starch) is digested in the terminal ileum and is used as bacterial substrate (Iji et al., 2003) promoting the proliferation inside the intestine. The use of enzymes in broiler diets has been associated with better nutrient utilization which resulted from the lower pathogen colonization (Mathlouthi et al., 2002).

Newcastle disease is a contagious and fatal viral infection affecting all species of birds and is caused by the virus Paramyxovirus type 1 (Ali et al., 2004). Maternal antibodies protect birds during the first week of age and can interfere with the development of humoral immunity; however, they can not avoid the rapid establishment of the vaccine protection (Kouwenhoven, 1993).

The infectious disease of the bursa, named Gumboro, is a viral infectious-contagious poultry disease that affects the Bursa of Fabricius, an important organ for the immune system development of young chicken (Kneipp, 2000). Vaccinating breeding hens with live attenuated or inactivated virus vaccine has more effectively controlled the disease. Induced antibodies are transferred to the young chicks via the egg yolk (Alam et al., 2002). According to Skeeles et al. (1979), the levels of maternal antibodies against Gumboro in chicks lasted three to five days.

This trial aimed to evaluate the effects of including MOS and/or enzymes in broiler diets on antibody titers against Gumboro and Newcastle disease.

\section{MATERIAL AND METHODS}

A total of 750 one-day-old Cobb male chicks with initial weight $41.51 \pm 0.59 \mathrm{~g}$ were used in the trial. The birds were distributed into a completely randomized experimental design in a factorial arrangement $2 \times 2+1$, with two levels of $\mathrm{MOS}^{1}$ ( 0 and $0.1 \%$ until 21 days and $0.05 \%$ from 22 to 42 days of age), two levels of enzymes ${ }^{2}$ ( 0 and $0.05 \%$ ) and a positive control diet with $125 \mathrm{ppm}$ of colistin sulfate and $10 \mathrm{ppm}$ of virginiamycin as growth promoters and $51 \mathrm{ppm}$ of salinomycin as anticoccidial, totaling five treatments and five replicates. The diet without no antibiotics, MOS or enzymes was considered as a negative control.

Phytase $^{3}$ with minimum activity of $250 \mathrm{U} / \mathrm{g}$ was included in all the diets and the concentration of non-phytate phosphorus was $0.38 \%$, corresponding to $85 \%$ of reduction in birds requirements. Enzymes (liquid form) were composed of cellulase, protease, and $\alpha$-amylase and were premixed to $500 \mathrm{~g}$ of soybean meal before mixture.

The experimental diets were isonutritional and formulated according to Rostagno et al. (2000), except for metabolizable energy and crude protein that corresponded to $98 \%$ of the nutritional levels described by the same authors. Feed and water were supplied ad libitum during the experimental period.

Chickens were originated from breeder batches vaccinated against Gumboro disease at 14, 25,

\footnotetext{
${ }^{1,2}$ Bio-Mos and Allzyme Vegpro Liquid - Alltech do Brasil

Agroindustrial Ltda. - Araucária, Brazil.

${ }^{3}$ Allzyme Phytase 2X - Alltech Inc. - Nicholasville, USA.
} 
and 36 days and 10, 15, and 22 weeks of age, and against Newcastle disease at 14 and 36 days and 10,15 , and 22 weeks of age. All the vaccines contained live virus, except for those applied in the $22^{\text {nd }}$ week. The progeny chickens were vaccinated against IBDV at seven (attenuated live virus, Lukert strain) and 21 days of age (live virus, low attenuation sample, strain V877) and against Newcastle disease (live virus, type B1, strain B1) at 14 days of age, both by drinking water. Chickens were submitted to water fasting during two hours before vaccination.

For serum analysis, blood samples were weekly collected by jugular vein puncture in the same two chickens per replicate, from the first up to the $6^{\text {th }}$ week of age. Blood samples were centrifuged and serum was analyzed for antibody titers by ELISA carried out according to the manufacturer ${ }^{1}$. Optical density of each sample was obtained by Labsystems Genesis (version 3.03) program and used for antibody titers determination.

The results obtained of MOS x enzyme factorial were submitted to the analysis of variance using the SAEG software (Sistema..., 2001) and the means were compared by Fisher test at 5\% of probability.

\section{RESULTS AND DISCUSSION}

No significant interactions $(\mathrm{P}>0.05)$ of MOS $\mathrm{x}$ enzymes or positive control and MOS x enzymes factorial on antibody titers against IBDV (Table 1) and NDV (Table 2) were observed. However, the inclusion of MOS resulted in increased antibody titers against IBDV in the $4^{\text {th }}(\mathrm{P}<0.03)$ and $5^{\text {th }}(\mathrm{P}<0.02)$ weeks, and against NDV in the $3^{\text {rd }}(\mathrm{P}<0.01), 4^{\text {th }} \quad(\mathrm{P}<0.03)$, and $5^{\text {th }} \quad(\mathrm{P}<0.03)$ weeks of age. These results demonstrated the positive influence of MOS on the response to vaccination of the chickens immune system.

Vaccination against IBDV occurred at the end of the first week of age. In the $2^{\text {nd }}$ and $3^{\text {rd }}$ weeks of age, vaccinal antibodies increased and reached the production peak. Antibody titers resulting from the first vaccination were already decreasing in the $4^{\text {th }}$ week. The second vaccination occurred at the end of the $3^{\text {rd }}$ week and the peak of antibodies produced was reached in the $5^{\text {th }}$ week. Ingestion of diets containing MOS resulted in more high titers, in comparison to birds which were fed diets without additives or only with enzymes, specifically during the weeks in which titers tended to decrease.

Table 1. Antibody titers $\left(\log _{10}\right)$ specific to infectious bursal disease virus in broilers fed diets with or without MOS and/or enzymes

\begin{tabular}{|c|c|c|c|c|c|c|}
\hline \multirow{2}{*}{$\begin{array}{c}\text { Age } \\
\text { (week) }\end{array}$} & \multirow{2}{*}{$\begin{array}{c}\text { Positive } \\
\text { control } \\
\end{array}$} & \multirow[b]{2}{*}{ MOS } & \multicolumn{2}{|c|}{ Enzymes (\%) } & \multirow[b]{2}{*}{ Mean } & \multirow[b]{2}{*}{ SEM } \\
\hline & & & without & with & & \\
\hline \multirow{3}{*}{$1^{\text {st }}$} & & without & 2.79 & 2.83 & 2.81 & \\
\hline & & with & 2.76 & 2.99 & 2.88 & \\
\hline & 2.75 & mean & 2.77 & 2.91 & & 0.05 \\
\hline \multirow{3}{*}{$2^{\text {nd }}$} & & without & 2.19 & 2.47 & 2.33 & \\
\hline & & with & 2.43 & 2.61 & 2.52 & \\
\hline & 2.88 & mean & 2.31 & 2.54 & & 0.08 \\
\hline \multirow{3}{*}{$3^{\text {rd }}$} & & without & 2.38 & 2.55 & 2.47 & \\
\hline & & with & 2.51 & 2.75 & 2.63 & \\
\hline & 2.53 & mean & 2.44 & 2.65 & & 0.06 \\
\hline \multirow{3}{*}{$4^{\text {th }}$} & & without & 1.81 & 2.08 & $1.94 b$ & \\
\hline & & with & 2.45 & 2.36 & $2.40 \mathrm{a}$ & \\
\hline & 1.93 & mean & 2.13 & 2.22 & & 0.08 \\
\hline \multirow{3}{*}{$5^{\text {th }}$} & & without & 2.48 & 2.54 & $2,51 b$ & \\
\hline & & with & 2.67 & 2.78 & $2.73 a$ & \\
\hline & 2.71 & mean & 2.58 & 2.66 & & 0.04 \\
\hline \multirow{3}{*}{$6^{\text {th }}$} & & without & 2.76 & 2.71 & 2.73 & \\
\hline & & with & 2.57 & 2.62 & 2.69 & \\
\hline & 2.70 & mean & 2.66 & 2.66 & & 0.04 \\
\hline
\end{tabular}

Means followed by different letters, in the same column, differ by Fisher test $(\mathrm{P}<0.05)$.

SEM: standard error of mean.

${ }^{1}$ Kit - FlockCheck - IBD/NDV antibody ELISA - Idexx Laboratories, USA. 
Effect of mannanoligosaccharides...

Table 2. Antibody titer $\left(\log _{10}\right)$ against NDV in broilers fed diets with or without MOS and/or enzymes

\begin{tabular}{|c|c|c|c|c|c|c|}
\hline \multirow{2}{*}{$\begin{array}{c}\text { Age } \\
\text { (week) }\end{array}$} & \multirow{2}{*}{$\begin{array}{l}\text { Positive } \\
\text { control }\end{array}$} & \multirow[b]{2}{*}{ MOS } & \multicolumn{2}{|c|}{ Enzymes (\%) } & \multirow[b]{2}{*}{ Mean } & \multirow[b]{2}{*}{ SEM } \\
\hline & & & without & with & & \\
\hline \multirow{3}{*}{$1^{\text {st }}$} & & without & 3.11 & 3.13 & 3.12 & \multirow[b]{3}{*}{0.05} \\
\hline & & with & 3.08 & 3.06 & 3.07 & \\
\hline & 2.98 & mean & 3.09 & 3.10 & & \\
\hline \multirow{3}{*}{$2^{\text {nd }}$} & & without & 2.14 & 2.18 & 2.16 & \\
\hline & & with & 2.52 & 2.04 & 2.28 & \multirow[b]{2}{*}{0.07} \\
\hline & 2.55 & mean & 2.33 & 2.11 & & \\
\hline \multirow{3}{*}{$3^{\text {rd }}$} & & without & 1.47 & 1.50 & $1.49 b$ & \\
\hline & & with & 1.87 & 2.20 & $2.04 \mathrm{a}$ & \multirow[b]{2}{*}{0.09} \\
\hline & 1.93 & mean & 1.67 & 1.85 & & \\
\hline \multirow{3}{*}{$4^{\text {th }}$} & & without & 2.47 & 2.28 & $2.38 b$ & \\
\hline & & with & 2.69 & 2.86 & $2.78 \mathrm{a}$ & \multirow[b]{2}{*}{0.09} \\
\hline & 2.93 & mean & 2.58 & 2.57 & & \\
\hline \multirow{3}{*}{$5^{\text {th }}$} & & without & 2.44 & 2.69 & $2.51 \mathrm{~b}$ & \multirow{4}{*}{0.06} \\
\hline & & with & 2.64 & 2.99 & $2.81 \mathrm{a}$ & \\
\hline & 2.72 & mean & 2.54 & 2.79 & & \\
\hline \multirow{3}{*}{$6^{\text {th }}$} & & without & 2.76 & 2.87 & 2.82 & \\
\hline & & with & 2.93 & 3.02 & 2.97 & \multirow[b]{2}{*}{0.08} \\
\hline & 2.66 & mean & 2.84 & 2.94 & & \\
\hline
\end{tabular}

Means followed by different letters, in the same column, differ by Fisher test $(\mathrm{P}<0.05)$.

SEM: standard error of mean.

Vaccination occurred in the $2^{\text {nd }}$ and $3^{\text {rd }}$ weeks of age, antibodies was increasing, and reached its peak in the $4^{\text {th }}$ week, and declined again at the $5^{\text {th }}$ week. During the whole period of vaccinal antibodies formation, MOS ingestion resulted in higher antibody titers and hence, in a better immunity.

During the period of antibody formation, due to vaccination, MOS exerted a positive effect on the immune system as much for vaccination against IBDV as for vaccination against NDV. Therefore, it is possible to assume that in a new stimulus, due to the contact with the infectious agent, there would be also a greater antibody production in birds fed the diets containing MOS.

The first reason for the positive effects of MOS was that it is a component of microorganisms considered as a pathogen, like the yeast cells, for example. Thus, this substance may be considered as a stranger compound to the host and result in increased immune response. The immune response is mediated by macrophages activation since macrophages have mannans binding receptors, as demonstrated by McKenzie et al. (1998).
MOS also may modulate humoral immunity against the colonization of specific pathogens, allowing them to be presented to immune cells as attenuated antigens due the production of short chain fatty acid (SCFA) derived from MOS fermentation that decreases intestinal $\mathrm{pH}$ and reduces the presence of pathogenic bacteria. Butyrate is one of the SCFA produced and its deficiency is associated with intestinal atrophy and functional fails, including decreased immune response (Brouns et al., 2002). However, an increased butyrate supply leads to the development of intestinal epithelium, cell differentiation, and increased immune response, probably due to the higher number of T-cells in the intestine (Peuranen et al., 2004).

In addition, MOS may also serve as an alternate attachment site in the gut for Gram-negative pathogenic organisms with mannose-specific type-1 fimbriae, which adhere to intestinal epithelial cells to initiate the colonization. These bacteria bind to MOS present in the intestinal tract and pass through the gut, instead of attaching to host epithelial cells.

The ingestion of prebiotics increases the Lactobacillus and Bifidobacterium colonization and the immune system may be modulated by 
these bacteria. Lactobacillus is considered as an immunomodulator due its ability to reduce the bacterial translocation in animals (Lee et al., 2000), while Bifidobacterium stimulates the antibody production (Bornet et al., 2002).

It is also possible that MOS may enhanced the secretion of plasma serum $\operatorname{IgG}$ and intestinal mucosa IgA, increasing the number of lymphocytes and/or leukocytes in the gutassociated lymphoid tissue (Field et al., 1999) and in peripheral blood (Kaufhold et al., 2000). In the intestine, secretory IgA binds to pathogenic organisms and provides protection by preventing their attachment to mucosal cells (Abbas et al., 2000).

Similar results were obtained by Savage et al. (1996) with the inclusion of $0.11 \%$ MOS in turkey diets and by O'Carra (1998) with the inclusion of $0.2 \%$ MOS in dog diets. Both studies demonstrated an increase in the antibody concentration in animals fed diets containing MOS. A more recent study has demonstrated an increase in the antibody titers against IBDV and NDV after the inclusion of 0.1 to $0.3 \%$ MOS in breeders (Afzali and Devegowda, 1999) and in their progenies (Raju and Devegowda, 2002).

However, Shafey et al. (2001) did not notice significant differences between treatments (with or without MOS) on antibody titers against IBDV and Newcastle diseases in chickens. Grieshop et al. (2004) evaluated the effects of including fructooligosaccharides and/or MOS in dog diets and the results did not show any difference on ileal $\operatorname{IgA}$, IgG, and serum $\operatorname{IgM}$ concentrations.

\section{CONCLUSION}

Considering the vaccination program used in the present study, the inclusion of MOS in broiler diets increased the immune response to vaccinations against IBDV and NDV.

\section{REFERENCES}

ABBAS, A.K.; LICHTMAN, A.H.; POBER, J.S. Cellular and molecular immunology. 4.ed. Philadelphia: W.B. Saunders, 2000. 553p.

AFZALI, N.; DEVEGOWDA, G. Ability of modified mannanoligosaccharide to counteract aflatoxicosis in broiler breeder hens. Poult. Sci., v.78, p.52, 1999. (Abstract).

ALAM, J.; RAHMAN, M.M.; SIL, B.K. et al. Effect of maternally derived antibody on vaccination against infectious bursal disease (Gumboro) with live vaccine in broiler. Int. J. Poult. Sci., v.1, p.98-101, 2002.

ALI, A.S.; ABDALLA, M.O.; MOHAMMED, M.E.H. Interaction between Newcastle disease and infectious bursal disease vaccines commonly used in Sudan. Int. J. Poult. Sci., v.3, p.300-304, 2004.

BORNET, F.R.J.; BROUNS, F.; TASHIRO, Y. et al. Nutritional aspects of short-chain fructooligosaccharides: natural occurrence, chemistry, physiology and health implications. Dig. Liver Dis., v.34, p.S111-S120, 2002.

BROUNS, F.; KETTLITZ, B.; ARRIGONI, E. Resistant starch and "the butyrate revolution". Trends Food Sci. Technol., v.13, p.251-261, 2002.

FERKET, P.R. Alternatives to antibiotics in poultry production: responses, practical experience and recommendations. In: ALLTECH'S ANNUAL SYMPOSIUM, 20., 2004, Lexington. Proceedings... Nottingham, UK: Nottingham University, 2004. p.54-67.

FIELD, C.J.; McBURNEY, M.I.; MASSIMINO, S. et al. The fermentable fiber content of the diet alters the function and composition of canine gut associated lymphoid tissue. Vet. Immunol. Immunopathol., v.72, p.325-341, 1999.

GRIESHOP, C.M.; FLICKINGER, E.A.; BRUCE, K.J. et al. Gastrointestinal and immunological responses of senior dogs to chicory and mannan-oligosaccharides. Arch. Anim. Nutr., v.58, p.483-493, 2004.

IJI, P.A.; KHUMALO, K.; SLIPPERS, S. et al. Intestinal function and body growth of broiler chickens on diets based on maize dried at different temperatures and supplemented with a microbial enzyme. Reprod. Nutr. Dev., v.3, p.7790, 2003.

KAUFHOLD, J.; HAMMON, H.M.; BLUM, J.W. Fructo-oligosaccharide supplementation: effects on metabolic, endocrine and hematological traits in veal caves. J. Vet. Med. A, v.47, p.17-29, 2000. 
KNEIPP, C.A.F. Doença de Gumboro no Brasil. In: SIMPÓSIO DE SANIDADE AVÍCOLA, 2., 2000, Santa Maria. Anais... Santa Maria: Embrapa, 2000. p.79-88.

KOCHER, A.; CHOCT, M.; ROSS, G. et al. Effects of enzyme combinations on apparent metabolizable energy of corn-soybean mealbased diets in broilers. J. Appl. Poult. Res., v.12, p.275-283, 2003.

KOUWENHOVEN, B. Newcastle disease. In: FERRAN, J.B.; Mc NULTY, M.S. Virus infections of birds. Amsterdam: Elsevier Science, 1993. p.341-361.

LEE, D.J.; DRONGOWSKI, R.A.; CORAN, A.G. et al. Evaluation of probiotic treatment in a neonatal animal model. Pediatr. Surg. Int., v.16, p.237-242, 2000 .

MATHLOUTHI, N.; LALLÈS, J.P.; LEPERCQ, $P$. et al. Xylanase and $\beta$-glucanase supplementation improve conjugated bile acid fraction in intestinal contents and increase villus size of small intestine wall in broiler chickens fed a rye-based diet. J. Anim. Sci., v.80, p.27732779, 2002.

McKENZIE, I.F.C.; APOSTOLOPOULOS, V.; LEES, C. et al. Oxidised mannan antigen conjugates preferentially stimulate $\mathrm{T} 1$ type immune responses. Vet. Immunol. Immunopathol., v.63, p.185-190, 1998.

O'CARRA, R. Boosting immune response in dogs: a role for dietary mannan sugars. In: ALLTECH'S ANNUAL SYMPOSIUM, 14., 1998, Lexington. Proceedings... Nottingham, UK: Nottingham University, 1998. p.563-572.

PATTERSON, J.A.; BURKHOLDER, K.M. Application of prebiotics and probiotics in poultry production. Poult. Sci., v.82, p.627-631, 2003.
PEURANEN, S.; TIIHONEN, K.; APAJALAHTI, $J$. et al. Combination of polydextrose and lactitol affects microbial ecosystem and immune responses in rat gastrointestinal tract. Br. J. Nutr., v.91, p.905914, 2004.

RAJU, M.V.L.N.; DEVEGOWDA, G. Esterified-glucomannan in broiler chickens dietscontaminated with aflatoxin, ochratoxin and T-2 toxin: evaluations of its binding ability (in vitro) and efficacy as immunomodulator. Asian-Austr. J. Anim. Sci., v.15, p.1051-1056, 2002.

ROSTAGNO, H.S.; ALBINO, L.F.T.; DONZELE, J.L. et al. Tabelas brasileiras para aves e suínos. Composição de alimentos $\mathrm{e}$ exigências nutricionais. Viçosa: UFV, 2000. $141 \mathrm{p}$.

SAVAGE, T.F.; COTTER, P.F.; ZAKRZEWSKA, E.I. The effects of feeding a mannan oligosaccharide on immunoglobulins, plasma IgG and bile IgA, of Wrolstad MW male turkeys. Poult. Sci., v.75, suppl.1, p.143, 1996. (Abstract).

SHAFEY, T.M.; AL-MUFAREJ, S.; SHALABY, M.I. et al. Effects of mannan oligosaccharides on antibody response to infectious bronchitis, infectious bursal disease and Newcastle disease in chickens. J. Appl. Anim. Res., v.19, p.117-127, 2001.

SHASHIDHARA, R.G.; DEVEGOWDA, G. Effect of dietary mannan oligosaccharide on broiler breeder production traits and immunity. Poult. Sci., v.82, p.1319-1325, 2003.

SISTEMA de análises estatísticas - SAEG. Versão 8.0. Viçosa: UFV, 2001. 150p.

SKEELES, J.K.; LUKERT, P.D.; FLETCHER, O.J. et al. Immunization studies with a cellculture-adapted infections bursal disease virus. Avian Dis., v.23, p.456-465, 1979. 